\title{
PERFORMANCE TEST OF 2.5 KW DC BOOST CONVERTER FOR NANOGRID SYSTEM APPLICATIONS
}

\author{
Jamsep Andreas ${ }^{1}$, Eko Adhi Setiawan ${ }^{1,2^{*}}$, Suharsono Halim², Muhamad Atar ${ }^{2}$, Hanifati Nur \\ Shabrina $^{2}$ \\ ${ }^{1}$ Department of Electrical Engineering, Faculty of Engineering, Universitas Indonesia, Kampus UI \\ Depok, Depok 16424, Indonesia \\ ${ }^{2}$ Tropical Renewable Energy Center (TREC), Faculty of Engineering, Universitas Indonesia, \\ Kampus UI Depok, Depok 16424, Indonesia
}

(Received: June 2018 / Revised: August 2018 / Accepted: October 2018)

\begin{abstract}
The development of power electronics continues to grow rapidly. One type of power electronics is the DC boost converter, which steps up DC voltage to another level. DC boost converters are widely used in many applications; for renewable energy, DC boost converters are very useful for stepping up DC voltage levels from nonconventional energy resources, such as photovoltaics, wind turbines, and fuel cells, to the main system. In this study, we tested a DC boost converter that has been developed to step up $48 \mathrm{~V}_{\mathrm{DC}}$ from energy storage to $235 \mathrm{~V}_{\mathrm{DC}}$ in the main bus. The DC boost converter will be used in the nanogrids system, developed by TREC and will supply household appliances such as televisions, lamps, laptops, and mobile phones. The performance tests showed between $+3 \%$ and $-1.2 \%$ of voltage deviation and $66-$ $98 \%$ efficiency.
\end{abstract}

Keywords: DC boost; Efficiency; Nanogrids; Performance test

\section{INTRODUCTION}

A DC-DC converter converts directly from DC voltage to another level of DC voltage. DC-DC converters are widely used for many applications, such as traction motor control in automobiles, trolley cars, marine hoists, forklift trucks, and mine haulers, to provide smooth acceleration control, high efficiency, and fast dynamic response (Rashid, 2004). DC-DC converters are divided into two main types: hard-switching pulse width modulated (PWM) converters and resonant, soft-switching converters. PWM converters are currently more commonly used because they have high efficiency, simple operational control, and a simple topology that uses fewer components. However, PWM converters experience significant losses at high switching.

PWM converter topology is generally divided into four types: buck converters (step down), boost converters (step-up), buck-boost converters (step-up/step-down), and Ḉuk converters. These four converter topologies are non-isolated DC-DC converter types, where the input voltage has the same grounding as the output voltage. Non-isolated DC-DC converters, with high static gain, have received the focus of research attention as there is a need for this technology in many applications, such as nonconventional energy sources like photovoltaic (PV) modules, small wind turbines, and fuel cells (Blaabjerg \& Ma, 2013; Ajami et al., 2015), which generate low DC voltages and need to be stepped up. Low voltages normally range from

\footnotetext{
*Corresponding author's email: ekoas@eng.ui.ac.id, Tel. +62-87-889974848, Fax.+62-21-7270077 Permalink/DOI: https://doi.org/10.14716/ijtech.v9i6.2429
} 
12 to $125 \mathrm{~V}$ and must be boosted to AC grid requirement voltage (Silveira et al., 2014).

This paper examines a DC boost converter used for nanogrids systems that is being developed by TREC, a research center at the University of Indonesia. Based on previous nanogrids research, there is more than one type of converter that can adjust the energy resource voltage into the voltage required for household appliances, such as $24 \mathrm{~V}_{\mathrm{DC}}$ or $48 \mathrm{~V}_{\mathrm{DC}}$. However, the proposed converter will boost $48 \mathrm{~V}_{\mathrm{DC}}$ from energy storage into $235 \mathrm{~V}_{\mathrm{DC}}$ for the main bus as the reference voltage, and then supply household appliances. Performance tests were conducted on this converter to determine its reliability and stability and, therefore, whether it would work well when applied to the nanogrids system. The nanogrids system is a power distribution system, as are microgrids (Adda et al., 2012b; Dong et al., 2013), but are different in capacity and topology. Nanogrids can operate in either off-grid or on-grid systems (Sivarasu et al., 2015) and have the ability to operate as AC, DC, or hybrid AC-DC. Nanogrids generally consist of a renewable energy source (Cvetkovic et al., 2012; Schönberger et al., 2006) and some sort of load that is based on the voltage rating (Adda et al., 2012a).

The basic components of nanogrids are:

1. Local power production derived from renewable energy, such as solar and wind, or fossil energy such as diesel generators or fuel cells.

2. Local loads are electrical household appliances in a house, such as televisions, lamps, and water heaters, which are supplied by local power.

3. A gateway that consists of a charge controller and power converter to convert DC voltage to AC or to DC voltage at another voltage level, to allow it to be distributed to the load.

4. A nanogrid control device, consisting of protection systems and component connections. Nanogrid control devices have the ability to transmit/receive electricity to/from the utility grid.

5. Energy storage, which stores and distributes the energy for balancing the system between supply and demand in the nanogrid.

Nanogrid topology can be divided into three types:

1. DC nanogrids. Generally, these systems use a DC voltage of $380 \mathrm{~V}_{\mathrm{DC}}$ on the main bus and convert the voltage, using a converter, to 24 or $48 \mathrm{~V}_{\mathrm{DC}}$ to meet the load requirement. The main bus voltage can be supplied by renewable energy, such as PV systems, or a utility grid converted to DC voltage.

2. AC nanogrids. These systems use AC voltage of 100-230 $\mathrm{V}_{\mathrm{AC}}$ on the main bus, depending on technical regulations. The energy source used in this technology is AC but can also use DC sources, such as PV, which is converted to AC voltage. This system can also use DC load supplied by power adapters or AC-DC converters with switch mode power supply (SMPS) technology (Setiawan et al., 2017).

3. Hybrid AC-DC nanogrids, a combination of the two previous systems. There are two main buses in such systems, for AC and DC voltages. Load separation is carried on these systems according to the main bus.

\section{DC BOOST CONVERTER}

A DC boost converter is a step-up DC converter with an output voltage higher than the input. The main components of PWM DC boost converters are VS (DC voltage input), L (inductor), D (diode), S (switching component), C (capacitor to filter output voltage), and R (resistive load).

Figure 1 shows the basic circuit of a DC boost converter. When the switching component is in the closed position (on state), the current in the inductor will be stored and the current of $\mathrm{I}_{\mathrm{L}}$ will increase linearly. The diode will be in the reverse bias condition because the inductor voltage is 
greater than output voltage. When the switching component is in the open position (off state), the energy stored in the inductor will flow to the load. The current will pass through the diode into the capacitor and resistor because the diode is in the forward bias condition and assumes no voltage drop in the diode. In steady state and continuous conduction mode, the total change in the induced current must be zero.

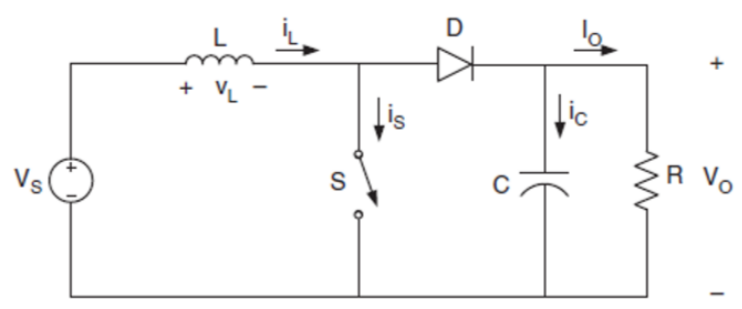

Figure 1 DC boost converter basic circuit

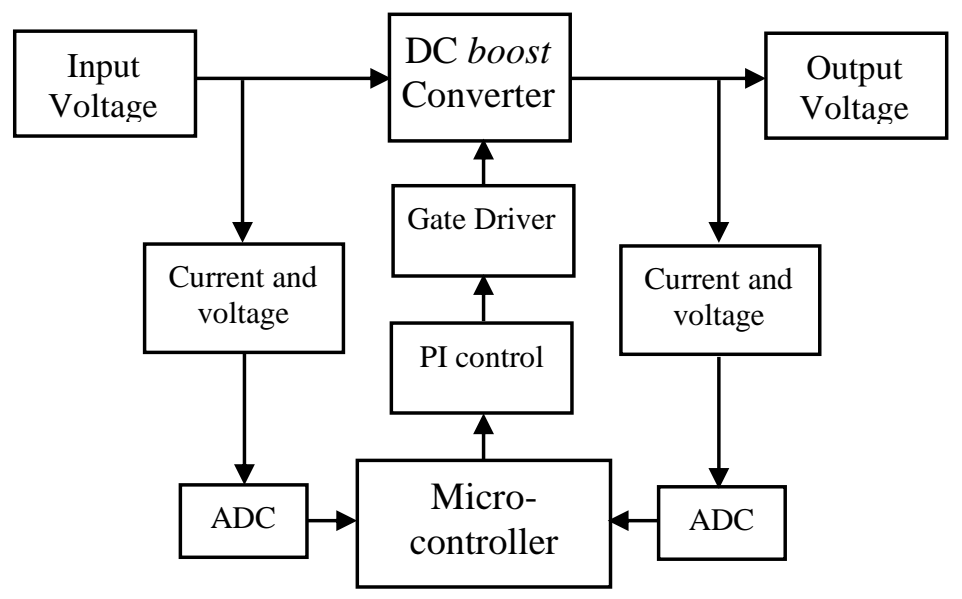

Figure 2 DC boost converter block diagram

\subsection{Boost Converter System}

Figure 2 show the design of a DC boost converter system. It is divided into four main parts; first is a microcontroller that acts as a control center converter to keep the output voltage stable at a nominal desired voltage - in this research, $235 \mathrm{~V}_{\text {DC }}$. Second is Insulated Gate Bipolar Transistor (IGBT) gate driver that amplifies the PWM signal from the pulse generator on the microcontroller to the gate on the IGBT. Third is a series of input and output voltage and current sensors to filter noise from the input signal due to the high frequency switching process, so the signal can be read correctly as feedback by the microcontroller. Fourth is the power supply, as the source for all components, so they can work optimally and stably. The power supply used is a linear regulator.

The converter voltage setting uses a PI (proportional integral) controller. The control system will adjust the duty cycle depending on the output of the converter. The purpose of the control system is to obtain appropriate $\mathrm{Kp}, \mathrm{Ki}$, and $\mathrm{Kd}$ values to ensure a stable system and to keep the converter output voltage at its specified value of $235 \mathrm{~V}_{\text {DC }}$. The control design research for this converter has been conducted previously (Shabrina et al., 2017). Figure 3 is a Simulink diagram of the converter simulation design. 


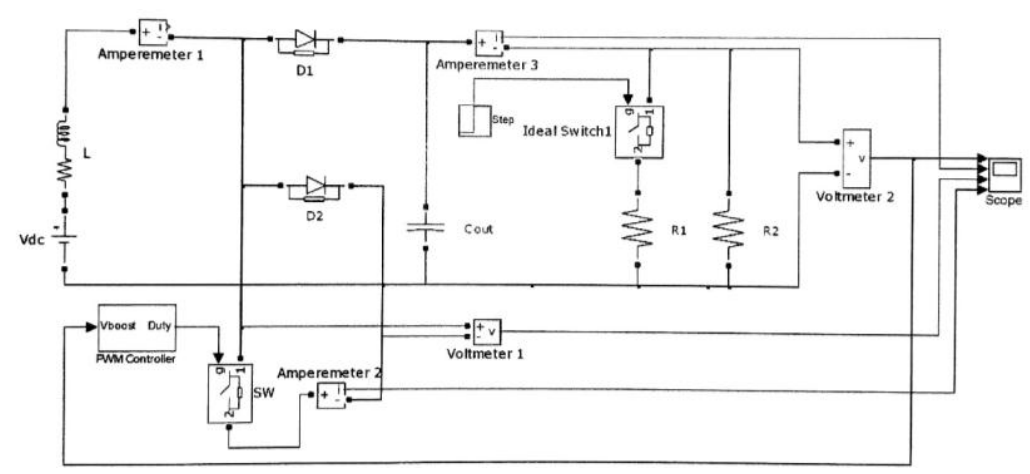

Figure 3 Simulink diagram of DC boost converter simulation design

\subsection{Boost Converter Design}

The DC boost converter can be seen in Figure 4, with a mica casing and heatsink at the bottom to spread the heat from the circuit, particularly the switching component, which produces more heat than the other components, to the environment. The specifications of this converter can be seen in Table 1. These specifications are designed with reference to the nanogrid concept requirements.

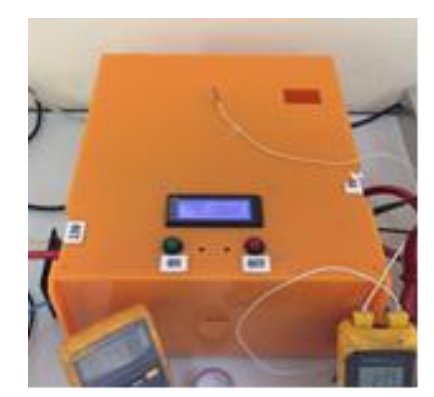

Figure 4 DC boost converter with mica casing

Table 1 DC boost converter specifications

\begin{tabular}{lc}
\hline \multicolumn{1}{c}{ Parameter } & Value \\
\hline Input voltage & $48 \mathrm{~V}_{\mathrm{DC}}$ \\
Output voltage & $235 \mathrm{~V}_{\mathrm{DC}}$ \\
Maximum power & $2.5 \mathrm{~kW}$ \\
Input current & $52.08 \mathrm{~A}$ \\
Output current & $10.87 \mathrm{~A}$ \\
\hline
\end{tabular}

\section{PERFORMANCE TEST DC BOOST CONVERTER}

Performance tests of the converter were conducted to determine voltage stability and efficiency. The test involved supplying a load to the converter (loads shown in Table 2) over the course of 3 hours, gradually increasing and decreasing from 0-2500 W. This test could assess the performance of the converter for each load because the total testing load was close to the capacity of the converter. In this test, the voltage output of the converter was set to $235 \mathrm{~V}_{\text {DC. }}$ The test measured the input and output voltage and current of the converter using an oscilloscope and multimeters. The input voltage source for the test was a $48 \mathrm{~V}$ DC power supply. Figure 3 shows the performance test setup of the converter. The test was conducted by capturing the input and output voltage and current every minute. 
Table 2 Performance test loads

\begin{tabular}{lcc}
\hline \multicolumn{1}{c}{ Load } & Unit & Load (Watt) \\
\hline CFL lamps & 2 & 63 \\
Electric solder & 2 & 100 \\
Water heater & 2 & 800 \\
Television & 1 & 240 \\
Rice cooker, cook mode & 3 & 1190 \\
Rice cooker, warm mode & 1 & 65 \\
\hline \multicolumn{1}{c}{ Total } & 2458 \\
\hline
\end{tabular}

The results of the test are shown in Figures 6 and 7, represented as voltage and efficiency graphs. In this test, the highest output voltage was $242 \mathrm{~V}_{\mathrm{DC}}$ and the lowest was $232 \mathrm{~V}_{\mathrm{DC}}$, for a voltage deviation $+3 \%$ and $-1.2 \%$ The average output voltage during the test was $235.15 \mathrm{~V}_{\mathrm{DC}}$ with a difference $0.15 \mathrm{~V}$, which was $0.06 \%$ from the voltage setting. The voltage deviation occurred when loads were charged and discharged from the converter. When the load was supplied, the current output increased, causing the output voltage converter to sag for a short time; conversely, when the load was discharged, the current decreased, resulting in a momentary output voltage swell. The instability of the output voltage in both conditions was due to the PI controller settings in the converter.

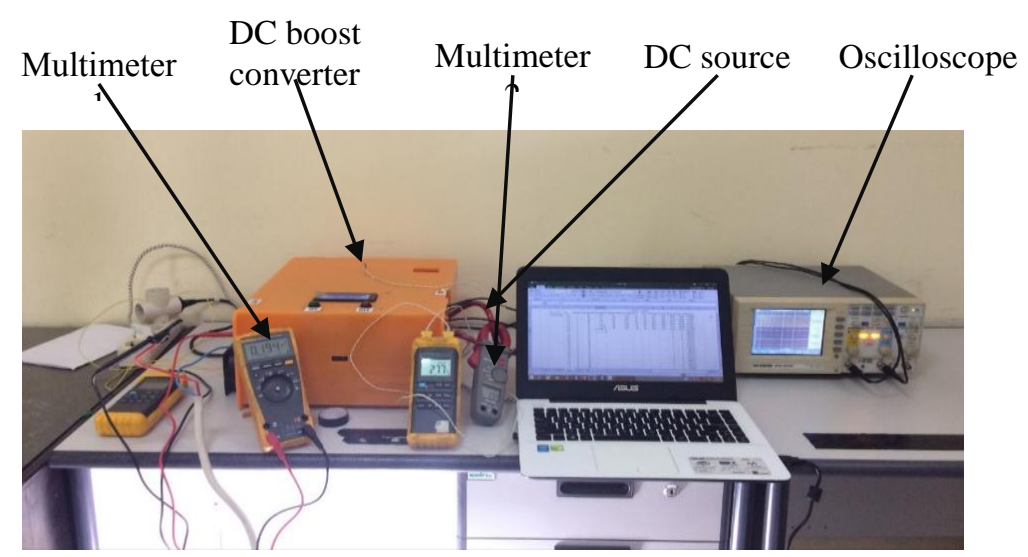

Figure 5 Set up of performance test DC boost converter

The two graphs in Figures 6 and 7 refer to the same period of time. In the efficiency measurement, the efficiency of the converter was 66-98\%. The efficiency saturated at 93-98\% when the loads were $930 \mathrm{~W}$ and above. There are several elements that affect efficiency switching losses and conduction losses that are generated by switching components, caused by the IGBT, and which depend on the temperature when the IGBT engages in switching activity, and conduction losses, which can be calculated using on-state current and voltage. In IGBT, the losses are due to RDS(on) resistance and depend on the temperature. The rectifier diode also contributes to conduction losses, due to the dissipation of the output current. 


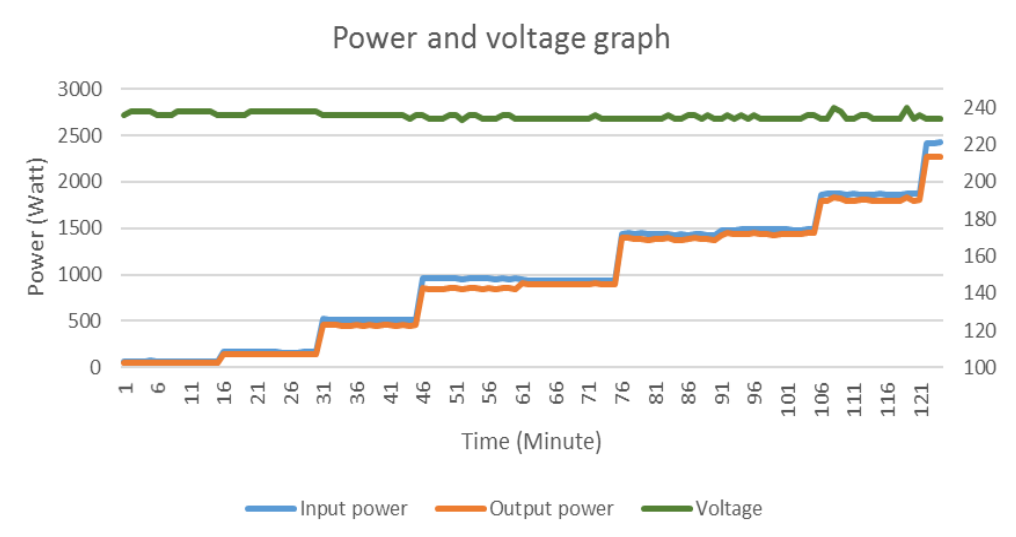

Figure 6 Voltage ratio againts supplied loads

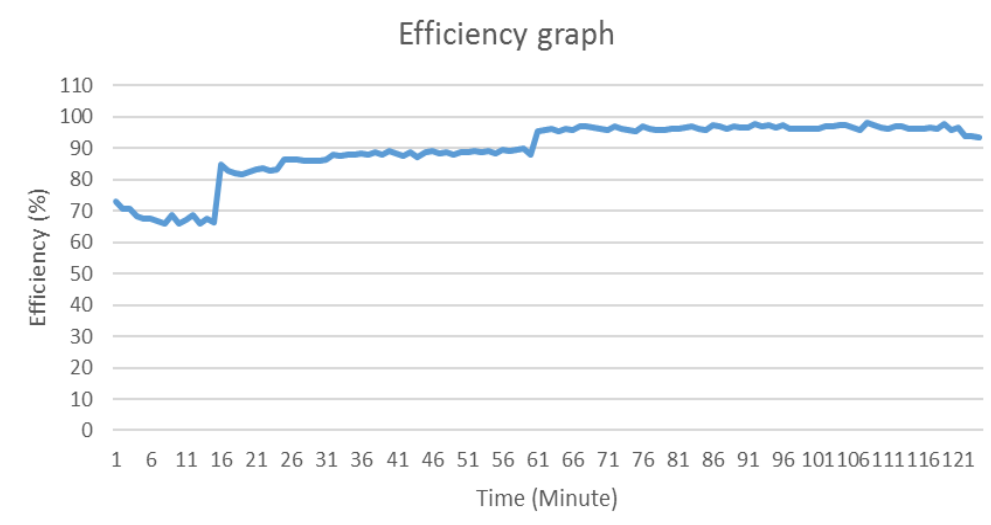

Figure 7 DC boost converter efficiency during performance test

Based on the calculations, the more load that was supplied, the more current was output and the greater the losses. Therefore, when load was supplied, efficiency decreased. However, this is not seen in the efficiency graph: converter efficiency decreased when the load or current were low. This is due to standby losses, which occur when the electronic components in the converter were activated before converting the voltage. Standby losses were constant with the loads supplied, and were generated by the converter under a no-load condition. At low load, standby losses can be very significant, resulting in converter efficiency in the range of 66-72\%. At high loads, standby losses are not significant and affect efficiency only slightly.

\section{IMPLEMENTATION}

Nanogrids are a relatively new research topic within the scope of power systems. However, nanogrid issues are growing rapidly with the increase in publications in international journals. Following are some examples of nanogrid research and development in various countries. A $380 V_{\text {DC }}$ DC nanogrid system was applied by Cvetkovic et al. (2012) to future buildings and tested at $1.8 \mathrm{~kW}$ resistive loads with $5 \mathrm{~kW}$ solar PV and $3.5 \mathrm{~kW}$ wind turbines as the power sources, and a 45 Ah energy storage. In Denmark (Tomas-Manez et al., 2017), DC nanogrids were built with two-level $400 \mathrm{~V}_{\mathrm{DC}}$ voltage at $\mathrm{HV}$ bus from the utility grid, and $48 \mathrm{~V}_{\mathrm{DC}}$ at $\mathrm{LV}$ bus from PV modules and a battery system. The purpose of this system was to determine the greatest efficiency during LV bus-supplied load in the HV bus, and vice versa, with $1 \mathrm{~kW}$ load capacity.

Sathler et al. (2017) discussed bidirectional grid interface converters (BGIC), which are responsible for the integration of DC nanogrids with the utility distribution system, managing 
the power exchange, complying with grid requirements, and protecting nanogrids from grid disturbances. In their study, BGICs converted $127 \mathrm{~V}_{\mathrm{AC}}$ from the utility grid to $380 \mathrm{~V}_{\mathrm{DC}} \mathrm{DC}$ voltage, with a power capacity of $2 \mathrm{~kW}$. In Japan, an interconnection between DC nanogrids was developed (Werth et al., 2015), which connected to a DC power bus with a nominal 350$380 \mathrm{VDC}$.

Research hybrid AC/DC nanogrids were developed at the Illinois Institute of Technology (Shahidehpour et al., 2017), in which AC loads and DC loads were separated with different voltage levels $-120 \mathrm{~V}_{\mathrm{AC}}$ for AC loads and $48 \mathrm{~V}_{\mathrm{DC}}$ for DC loads. AC voltage was supplied from the utility grid to supply AC loads and DC loads, using an AC/DC converter. DC voltage was supplied from the PV array to supply DC loads and AC loads, using a DC/AC converter. Another study examined hybrid AC/DC nanogrids with a capacity of $5 \mathrm{~kW}$ solar PV and a 10 $\mathrm{kW}$ bidirectional converter (Ebrahim et al., 2017). This had a DC main bus of $380 \mathrm{~V}_{\mathrm{DC}}$ from a $127 \mathrm{~V}_{\mathrm{RMS}}$ utility grid, and supplied the load through a DC/DC converter to adjust the load voltage at $24 \mathrm{~V}_{\mathrm{DC}}$ and $48 \mathrm{~V}_{\mathrm{DC}}$. The rating voltage of the $\mathrm{AC}$ bus was $100 \mathrm{~V}_{\mathrm{AC}}$, which was used to supply linear and nonlinear AC loads.

Based on these nanogrid developments, hybrid nanogrid topology appears to be lack effective and efficient for the following reasons:

1. The conversion of AC voltage into DC voltage from the utility grid to supply the loads, according to the nanogrid systems method, depends on the utility grid for supplying DC loads. However, the nanogrid principle is to feed electricity loads independently, using one or more local renewable/clean energy sources. The role of the utility grid is to compensate the loads during disturbances in the renewable energy sources.

2. The application of different DC voltage levels in nanogrid systems, such as the main bus 380 $\mathrm{V}_{\mathrm{DC}}$ converted to 24 and $48 \mathrm{~V}_{\mathrm{DC}}$ at the load side, would make nanogrid systems less effective and efficient due to a large number of converters in the system.

A new concept for nanogrids, called Dual Power, has been proposed as a solution for effective and efficient systems. The Dual Power concept uses two energy sources - AC voltage from the utility grid and DC voltage from $1.5 \mathrm{kWp} \mathrm{PV}$. This concept only requires one DC boost converter to step up the voltage from $48 \mathrm{~V}_{\mathrm{DC}}$ to $235 \mathrm{~V}_{\mathrm{DC}}$. Dual Power separates loads into two groups - load 1 at $220 \mathrm{~V}_{\mathrm{AC}}$ and load 2 at $235 \mathrm{~V}_{\mathrm{DC}}$ - to supply the loads. The DC source is supplied by a PV array whose output is connected to a battery through a charge controller. The output voltage from the PV array system is $48 \mathrm{~V}_{\mathrm{DC}}$ and would be boosted to $235 \mathrm{~V}_{\mathrm{DC}}$ by the DC boost converter. Load 1 is supplied by a DC boost converter or utility grid, while load 2 is supplied only by the utility grid. Load 1 can be supplied as AC and DC voltage because household loads have SMPS technology, which generally has an AC voltage input that is then converted into DC voltage by a rectification process using a rectifier and filter. When a DC voltage is used for SMPS input, it is simply passed by the rectifier diode to the next step. However, the DC voltage rating to energize electronic home appliances is not yet standardized. Dual Power is also compatible with universal motors, such as drills and grinder machines,

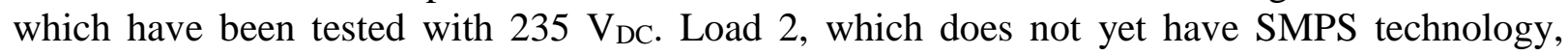
including water pumps, refrigerators, and air conditioners, would be separated and supplied only by AC voltage.

There are three operational modes in a Dual Power system, as shown in Table 3. To better understand this concept, the topology of the operational modes are described in Figure 8. In mode 1, both AC and DC sources supply their loads; the DC boost converter supplies load 1 (blue line) and the utility grid supplies load 2 (red line). Operational mode 2 occurs when the utility grid suffers an outage, so load 2 receives no power supply. The solution proposed for this condition is to convert $235 \mathrm{~V}_{\mathrm{DC}}$ into $220 \mathrm{~V}_{\mathrm{AC}}$, but this solution has not been implemented 
because Dual Power would eventually replace all household appliances to be supplied with 235 $\mathrm{V}_{\mathrm{DC}}$, and the system would become more efficient as it would then use only one $2.5 \mathrm{~kW} \mathrm{DC}$ boost converter. Operational mode 3 occurs when the PV system is in solar radiation conditions too low to charge the battery, and the battery capacity is not capable of supplying the load, so the utility grid directly supplies load 1 and load 2 without power conversion from AC to DC. Currently, the switching mode still uses a manual relay, but a smart relay is being developed to detect the battery voltage level that indicates that DC voltage cannot supply load 1 , at which point the smart relay would switch from mode 1 to mode 3 automatically.

Table 3 Existing dual power operational modes

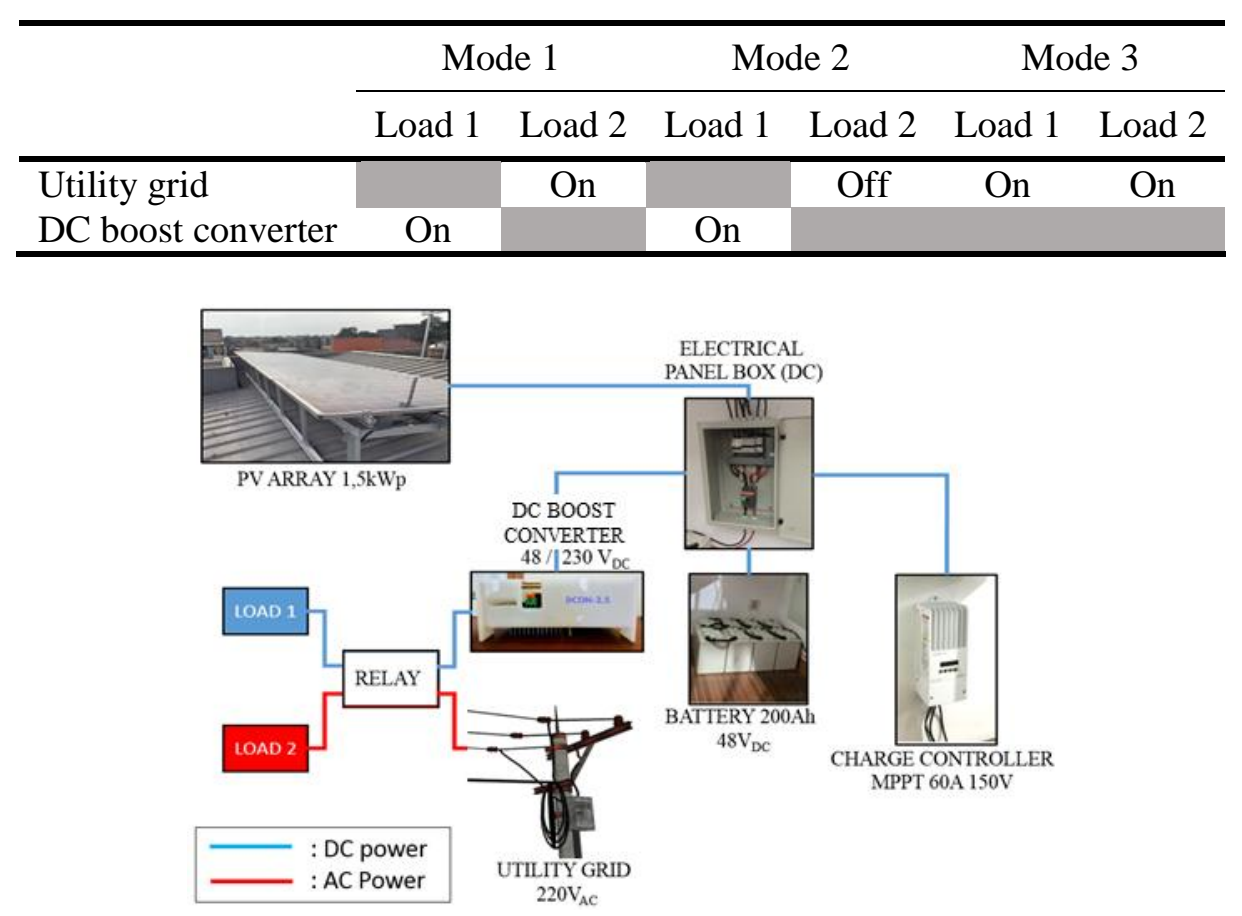

Figure 8 Implementation of Dual Power topology

Dual Power effectively has only two operational modes, as shown in Table 4 - modes 1 and 3 . This will apply when the entire household load has been replaced with modern equipment that can be supplied with $235 \mathrm{~V}_{\mathrm{DC}}$. In other words, DC voltage would become the main supply system and AC voltage would back up the supply when the DC boost converter is interrupted, making the Dual Power concept more effective and efficient.

Table 5 shows the specifications and components of the Dual Power system. The DC source of the Dual Power system is composed of PV arrays, charge controllers, batteries, and a DC boost converter. Figure 8 shows the layout of the Dual Power topology, implemented with all components combined in a panel box, as the control and protection center of the system.

Table 4 Future dual power operational modes

\begin{tabular}{|c|c|c|c|c|c|c|}
\hline & \multicolumn{2}{|c|}{ Mode 1} & \multicolumn{2}{|c|}{ Mode 2} & \multicolumn{2}{|c|}{ Mode 3} \\
\hline & Load 1 & Load 2 & Load 1 & Load 2 & Load 1 & Load 2 \\
\hline Utility grid & & & & & On & $\overline{\text { On }}$ \\
\hline DC boost converter & On & On & On & On & & \\
\hline
\end{tabular}


Table 5 Dual power implemented specifications

\begin{tabular}{ll}
\hline \multicolumn{1}{c}{ Component } & \multicolumn{1}{c}{ Specification } \\
\hline AC source & Utility grid $220 \mathrm{~V}_{\mathrm{AC}}$ \\
DC source & PV array $1.5 \mathrm{kWp}$ \\
Charge controller & MPPT 60 A $150 \mathrm{~V}$ \\
Battery & $200 \mathrm{Ah} 48 \mathrm{~V}_{\mathrm{DC}}$ \\
DC boost converter & $2.5 \mathrm{~kW} 48 / 235 \mathrm{~V}_{\mathrm{DC}}$ \\
\hline
\end{tabular}

\section{CONCLUSION}

The performance test of this converter achieved very stable output with $+3 \%$ and $-1.2 \%$ voltage deviation. The average output voltage was $235.15 \mathrm{~V}$, with a difference of $0.15 \mathrm{~V}$ or $0.06 \%$ from the setting value, meaning that the output voltage of the converter was quite stable. The converter efficiency in this test was $66-98 \%$. The low efficiency was affected by significant standby losses to the load supplied, while at high loads - above 930 watts - the converter efficiency was stable at 93-98\%. This indicates that the converter already has good efficiency for use in Dual Power, a new concept for nanogrid systems.

\section{ACKNOWLEDGEMENT}

This paper was supported and funded by the Hibah Program Pengembangan Teknologi Industri of the Ministry of Research, Technology, and Higher Education of the Republic of Indonesia, grant number 03/II/PPK/E/E4/2018.

\section{REFERENCES}

Adda, R., Ray, O., Mishra, S., Joshi, A., 2012a. Implementation and Control of Switched Boost Inverter for DC Nanogrid Applications. In: 2012 IEEE Energy Conversion Congress and Exposition (ECCE), Raleigh, 15-20 September, USA, pp. 3811-3818

Adda, R., Ray, O., Mishra, S., Joshi, A., 2012b. DSP-Based PWM Control of Switched Boost Inverter for DC Nanogrid Applications. In: IECON $2012-38^{\text {th }}$ Annual Conference on IEEE Industrial Electronics Society, Montreal, 25-28 October, Canada, pp. 5285-5290

Ajami, A., Ardi, H., Farakhor, A., 2015. A Novel High Step-up DC/DC Converter based on Integrating Coupled Inductor and Switched-capacitor Techniques for Renewable Energy Applications. IEEE Transactions on Power Electronics, Volume 30(8), pp. 4255-4263

Blaabjerg, F., Ma, K., 2013. Future on Power Electronics for Wind Turbine Systems. IEEE Journal of Emerging and Selected Topics in Power Electronics, Volume 1(3), pp. 139-152

Cvetkovic, I., Dong, D., Zhang, W., Jiang, L., Boroyevich, D., Lee, F.C., Mattavelli, P., 2012. A Testbed for Experimental Validation of a Low-voltage DC Nanogrid for Buildings. In: $201215^{\text {th }}$ International Power Electronics and Motion Control Conference, Novi Sad, 4-6 September, Serbia, pp. LS7c.5-1-LS7c.5-8

Dong, D., Cvetkovic, I., Boroyevich, D., Zhang, W., Wang, R., Mattavelli, P., 2013. Gridinterface Bidirectional Converter for Residential DC Distribution Systems-Part One: High-Density Two-Stage Topology. IEEE Transactions on Power Electronics, Volume 28(4), pp. 1655-1666

Ebrahim, A.F., Youssef, T.A., Mohammed, O.A., 2017. Power Quality Improvements for Integration of Hybrid AC/DC Nanogrids to Power Systems. In: 2017 Ninth Annual IEEE Green Technologies Conference (GreenTech), Denver, 29-31 March, USA, pp. 171-176 
Rashid, M.H., 2004. Power Electronics: Circuits, Devices, and Applications (3 ${ }^{\text {rd }}$ Edition). Pearson, USA

Sathler, H.H., Sathler, L.H., Marcelino, F.L.F., de Oliveira, T.R., Seleme, S.I., Garcia, P.F.D., 2017. A Comparative Efficiency Study on Bidirectional Grid Interface Converters Applied to Low Power DC Nanogrids. In: 2017 Brazilian Power Electronics Conference (COBEP), Juiz de Fora, 19-22 November, Brazil

Schönberger, J., Round, S., Duke, R., 2006. Autonomous Load Shedding in a Nanogrid using DC Bus Signa.lling. In: IECON 2006 - 32 $2^{\text {nd }}$ Annual Conference on IEEE Industrial Electronics, Paris, 6-10 November, France, pp. 5155-5160

Setiawan, E.A., Setiawan, A., Purnomo, A., Djamal, M.H., 2017. Determination of Appropriate DC Voltage for Switched Mode Power Supply (SMPS) Loads. In: AIP Conference Proceedings, Voluume 1826(1), pp. 020027-1-020027-6

Shabrina, H.N., Setiawan, E.A., Sabirin, C.R., 2017. Designing of New Structure PID Controller of Boost Converter for Solar Photovoltaic Stability. In: AIP Conference Proceedings, Voluume 1826(1), pp. 020026-1-020026-7

Shahidehpour, M., Li, Z., Gong, W., Bahramirad, S., Lopata, M., 2017. A Hybrid AC/DC Nanogrid: The Keating Hall Installation at the Illinois Institute of Technology. IEEE Electrification Magazine, Volume 5(2), pp. 36-46

Silveira, G.C., Tofoli, F.L., Bezerra, L.D.S., Torrico-Bascopé, R.P., 2014. A Nonisolated DCDC Boost Converter with High Voltage Gain and Balanced Output Voltage. IEEE Transactions in Industrial Electronics, Volume 61(12), pp. 6739-6746

Sivarasu, S.R., Chandira Sekaran, E., Karthik, P., 2015. Development of Renewable Energy Based Microgrid Project Implementations for Residential Consumers in India: Scope, Challenges and Possibilities. Renewable and Sustainable Energy Reviews, Volume 50, pp. 256-269

Tomas-Manez, K., Zhang, Z., Ouyang, Z., 2017. Unregulated Series Resonant Converter for Interlinking DC Nanogrids. In: 2017 IEEE 12 $2^{\text {th }}$ International Conference on Power Electronics and Drive Systems (PEDS), Honolulu, 12-15 December, USA

Werth, A., Kitamura, N., Tanaka, K., 2015. Conceptual Study for Open Energy Systems: Distributed Energy Network Using Interconnected DC Nanogrids. IEEE Transactions on Smart Grid, Volume 6(4), pp. 1621-1630 